\title{
Nutrient removal in a constructed wetland treating aquaculture effluent at short hydraulic retention time
}

\author{
Johanne Dalsgaard ${ }^{1, *}$, Mathis von Ahnen ${ }^{1}$, Christopher Naas ${ }^{1,2}$, \\ Per Bovbjerg Pedersen ${ }^{1}$
}

${ }^{1}$ Technical University of Denmark, DTU Aqua, Section for Aquaculture, 9850 Hirtshals, Denmark

${ }^{2}$ Institute of Inland Fisheries in Potsdam-Sacrow, 14469 Potsdam, Germany

\begin{abstract}
We examined the longitudinal and seasonal removal of dissolved and particulate nutrient components in a free water surface (FWS) constructed wetland treating all the effluent from a commercial recirculating rainbow trout Oncorhynchus mykiss farm. The wetland consisted of a meandering, $0.7 \mathrm{~m}$ deep channel with a total FWS area of $5811 \mathrm{~m}^{2}$, a total hydraulic loading rate (HLR) of $2.23 \mathrm{~m} \mathrm{~d}^{-1}$, and a total hydraulic retention time (HRT) of $0.32 \mathrm{~d}$. Bi-weekly, $24 \mathrm{~h} \mathrm{com-}$ posite samples were obtained along the wetland for $1 \mathrm{yr}$ and analysed for dissolved and particulate nutrient components. Furthermore, a short sampling campaign assessed the sedimentation of particles (5 to $200 \mu \mathrm{m}$ ). A first order kinetic plug flow model was fitted to the longitudinal data, and a first set of area-based removal rate constants $\left(k_{A}\right)$ for this wetland type was derived. Sedimentation led to particulate nutrient removal, but there was no annual net removal of dissolved nutrients aside from an infinitesimal removal of phosphorus. Microbial removal processes were substratelimited, and removal rate constants followed an annual cycle presumably coupled to available plant surface area and temperature. Denitrification was limited by low carbon availability and high oxygen concentrations, and the wetland became a net producer of nitrate at times due to oxygenation of ammonia. In summary, dissolved nutrients were largely not removed and the wetland was over-dimensioned for particulate nutrient removal. This new insight should be taken into account in future efforts to improve the treatment performance of similar types of aquaculture wetlands operated at short hydraulic retention times.
\end{abstract}

KEY WORDS: Recirculating aquaculture - End-of-pipe $\cdot$ Constructed wetland $\cdot$ Hydraulic retention time $\cdot$ Dissolved nutrients $\cdot$ Particulate nutrients

\section{INTRODUCTION}

Free water surface (FWS) constructed wetlands (Kadlec \& Wallace 2009) are applied by many Danish fish farmers as a low-cost and low-maintenance endof-pipe treatment technology for removing nitrogen $(\mathrm{N})$, phosphorus $(\mathrm{P})$, and organic matter from aquaculture effluents. The concept emanates from the work of an aquaculture task group who recommended that flow-through rainbow trout Oncorhyn-

${ }^{*}$ Corresponding author: jtd@aqua.dtu.dk chus mykiss farms be reconstructed into so-called recirculating 'Model Trout Farms' (MTF), as a means of increasing aquaculture production in Denmark without increasing the net environmental impact (Pedersen et al. 2003, Jokumsen \& Svendsen 2010).

The initial and most intensively recirculating MTF (type III) used ground water as make-up water and constructed new concrete-based rearing units mounted with in-farm mechanical and biological water cleaning technologies. The old earthen ponds,

() The authors 2018. Open Access under Creative Commons by Attribution Licence. Use, distribution and reproduction are unrestricted. Authors and original publication must be credited. 
no longer used for fish production and consequently emptied of fish, were applied as end-of-pipe treatment wetlands with long (20 to $50 \mathrm{~h}$ ) hydraulic retention times (HRTs). This was done by interconnecting the ponds in a meandering fashion and leading the effluent from the MTF through the interconnected ponds before finally discharging it (Danish Ministry of Environment 2006, Jokumsen \& Svendsen 2010).

The removal of total nitrogen (TN), total phosphorus (TP), and total organic matter (measured as the $5 \mathrm{~d}$ biochemical [TBOD 5 ] and chemical [TCOD] oxygen demand) was closely monitored at 8 wetlands for $2 \mathrm{yr}$, and average area-based removal rates were established assuming zero-order removal kinetics $\left(2.7,0.18,4.4\right.$, and $13.1 \mathrm{~g} \mathrm{~m}^{-2} \mathrm{~d}^{-1}$ for TN, TP, TBOD ${ }_{5}$, and TCOD, respectively; Svendsen et al. 2008). The results gave rise to the idea that 'bigger is better', and fish farmers were able to obtain larger feed allowances by constructing larger wetlands (Danish Ministry of Environment 2012). This also applied to the less intensively recirculating MTF (type I) that discharged more, and more dilute, effluent. A number of large wetlands with relatively short HRTs $(\sim 9 \mathrm{~h}$; Jokumsen \& Svendsen 2010) were therefore constructed assuming that the treatment efficiency was similar to that of MTF type III wetlands.

There is extensive literature regarding treatment wetlands in general (Carvalho et al. 2017), adeptly summarized and reviewed by Kadlec \& Wallace (2009) and Mitch \& Gosselink (2015). None of the reviews, however, deal with large, FWS constructed wetlands receiving a constant inflow of relatively dilute aquaculture effluents. Schulz et al. (2004) is, to our knowledge, the only study so far that has described FWS wetlands treating aquaculture effluents, while a few studies have examined the treatment efficiency of sub-surface flow (SSF) wetlands or combined FWS and SSF wetlands (e.g. Schulz et al. 2003, Lin et al. 2005, Sindilariu et al. 2007, 2008, 2009). The study by Schulz et al. (2004) specifically looked at the effect of HRT on nutrient removal by comparing 3 parallel and relatively small $\left(350 \mathrm{~m}^{2}\right)$ FWS wetlands. The wetlands treated parts of the effluent from a flow-through rainbow trout fingerling farm $\left(70 \mathrm{~m}^{3}\right)$ that operated

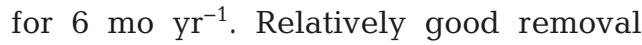
efficiencies of total suspended solids (TSS; 67 to $72 \%$ ), TCOD (30 to $31 \%$ ), TP (41 to $53 \%$ ), and TN (19 to $30 \%$ ) were found, and more TN and ammoniumnitrogen was removed at higher HRTs (comparing 3.5, 5.5, and $11 \mathrm{~h}$, respectively). Given the differences in system configurations, nutrient loadings and flow conditions, however, these results are not transferable to MTF type I constructed wetlands that continuously treat all the effluent from commercial scale recirculating MTFs.

The purpose of the current study was therefore to ascertain, and for the first time document, the longitudinal (i.e. effect of increasing HRT) and seasonal removal of $\mathrm{N}, \mathrm{P}$, and organic matter in a FWS wetland treating all the effluent from a commercial MTF type I. Furthermore, the purpose of the study was to derive a first set of removal rate estimates that may eventually contribute to sizing wetlands and predicting final outlet concentrations and masses from similar type fish farms. Rather than considering lumped (total) nutrients, the particulate and dissolved fractions of the different nutrient components were treated separately to better take into account different removal processes in the wetland.

\section{MATERIALS AND METHODS}

\section{Study site}

The study was carried out in a FWS constructed wetland associated with a Danish commercial MTF type I (Jokumsen \& Svendsen 2010, Fig. 1). The farm produced approximately 210 tons of portion-sized rainbow trout per year by applying 200 tons of commercial feed distributed more or less evenly throughout the yearly production cycle. Make-up water was pumped from the nearby stream (Stn A in Fig. 1) at a constant flow rate of $150 \mathrm{l} \mathrm{s}^{-1}$ and directed to 2 recir-

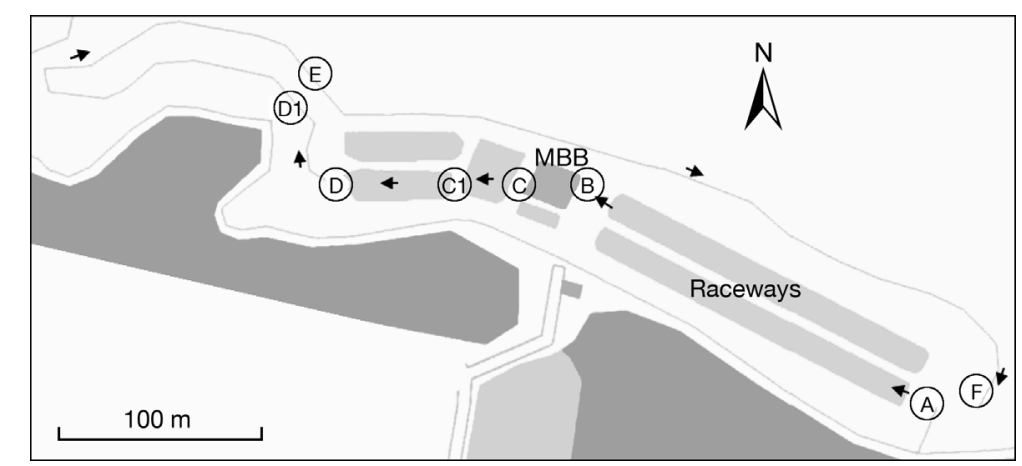

Fig. 1. Study site, showing the location of the farm water intake site (A), inlet to the moving bed biofilter (MBB, B), and wetland sampling stations $(\mathrm{C}$, C1, D, D1, E, F). Sampling Stn C was situated right after the moving bed biofilter feeding into the wetland while sampling Stns C1, D, D1, E and F were situated at increasing distance (i.e. increasing hydraulic retention time) along the wetland. Arrows indicate water flow direction 
culation units with a total volume of $2400 \mathrm{~m}^{3}$, corresponding to a system water exchange rate of 5.4 times $\mathrm{d}^{-1}$ (or a residence time of $4.4 \mathrm{~h}$ ). Water was recirculated using air lifts, and particles were removed in-farm via sludge cones and micro screens.

The farm effluent (Stn B in Fig. 1), corresponding in volume to the incoming make-up water, was pretreated in a moving bed biofilter to reduce the level of total ammonia nitrogen (TAN) prior to being polished in the wetland. In addition, the moving bed biofilter most likely caused further fragmentation of particles that had not been removed via in-farm micro screens.

Water flowed from the moving bed biofilter into the wetland via a weir at a constant flow rate equal to the continuously pumped intake flow to the farm. The flow rate into the wetland was verified by measuring the overflow at the weir. The first part of the wetland (Stns C to D in Fig. 1) consisted of 2 previous $0.8 \mathrm{~m}$ deep sedimentation basins, while the rest of the wetland (from Stns D to F in Fig. 1) consisted of a long, meandering, $0.7 \mathrm{~m}$ deep excavated channel. The outlet of the wetland to the local stream was situated immediately downstream of the pump inlet to avoid zones of reduced flow in the stream.

The constructed wetland had been in operation for several years prior to the study. It had a total FWS area $(A)$ of $5811 \mathrm{~m}^{2}$, a total volume $(V)$ of $4139 \mathrm{~m}^{3}$, and treated a flow $(Q)$ of $12960 \mathrm{~m}^{3} \mathrm{~d}^{-1}$, equal to the makeup water. The total hydraulic loading rate $(Q / A)$ was consequently $2.23 \mathrm{~m} \mathrm{~d}^{-1}$ and the total hydraulic retention time $(V / Q)$ in the wetland was $0.32 \mathrm{~d}$.

\section{Sampling and analysis}

Six successive sampling stations were situated along the wetland as detailed in Fig. 1 (Stns C, C1, D, D1, E, F) and Table 1. Composite $24 \mathrm{~h}$ samples were obtained from the middle of the water column once every 2 wk throughout a year (4 July 2013 to 12 June 2014, 25 sampling days in total) at sampling Stns A, C, D, E, and F, assuming a similar hydraulic profile throughout the excavated wetland. The samples were obtained using automatic, refrigerated samplers (Glacier® Portable, Teledyne ISCO) programmed to sample $300 \mathrm{ml}$ with $1 \mathrm{~h}$ intervals for $24 \mathrm{~h}$. Dissolved oxygen $\left(\mathrm{mg} \mathrm{O}_{2} \mathrm{I}^{-1}\right)$ and temperature $\left({ }^{\circ} \mathrm{C}\right)$ were measured at each sampling event using Hach Lange HQ40 multimeters (Hach Lange).

Samples were analysed for $\mathrm{TN}, \mathrm{TBOD}_{5}, \mathrm{TCOD}$, and TP upon return to the laboratory as described below for the corresponding dissolved nutrients, ensuring that homogenous subsamples were ob-
Table 1. Wetland sampling stations cf. Fig. 1 positioned at increasing hydraulic retention time (HRT). FWS: free water surface

\begin{tabular}{|lcccc|}
\hline $\begin{array}{l}\text { Sampling } \\
\text { station }\end{array}$ & $\begin{array}{c}\text { FWS area } \\
\left(A, \mathrm{~m}^{2}\right)\end{array}$ & $\begin{array}{c}\text { Volume } \\
\left(V, \mathrm{~m}^{3}\right)\end{array}$ & $\begin{array}{c}\mathrm{HRT}^{\mathrm{a}} \\
(\mathrm{d})\end{array}$ & $\begin{array}{c}\text { Horizontal } \\
\text { flow velocity } \\
\left(q, \mathrm{~m} \mathrm{~d}^{-1}\right)\end{array}$ \\
\hline $\mathrm{C}$ & 0 & 0 & 0.00 & - \\
$\mathrm{C} 1$ & 360 & 288 & 0.02 & 36.0 \\
$\mathrm{D}$ & 720 & 576 & 0.04 & 18.0 \\
$\mathrm{D} 1$ & 934 & 787 & 0.06 & 13.9 \\
$\mathrm{E}$ & 3782 & 2711 & 0.21 & 3.4 \\
$\mathrm{~F}$ & 5811 & 4105 & 0.32 & 2.2 \\
\multicolumn{5}{|c}{} \\
${ }^{\mathrm{a}} V / Q$, where $Q$ (inlet flow rate $)=12960 \mathrm{~m}^{3} \mathrm{~d}^{-1}$ \\
${ }^{\mathrm{b}} Q / A$
\end{tabular}

tained at all times by gently shaking the sampling containers.

A set of sub-samples were filtered through $0.2 \mu \mathrm{m}$ sterile syringe filters (Filtropur $\mathrm{S}$ 0.2) prior to analysis

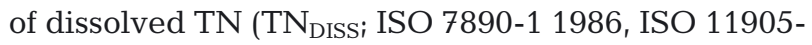
1 1997), TAN (DS 224 1975), nitrate $\left(\mathrm{NO}_{3}-\mathrm{N}_{i}\right.$ ISO 7890-1 1986), and nitrite ( $\mathrm{NO}_{2}-\mathrm{N}$; DS 223 1991). Another set of sub-samples were filtered through $1.6 \mu \mathrm{m}$ glass microfiber filters (Whatman ${ }^{\circledR}$ GF/A, GE Healthcare) and analysed for dissolved $\mathrm{BOD}_{5}\left(\mathrm{BOD}_{5 \text {-DISS }}\right.$ ISO 5815-2 2003), dissolved COD (COD DISSi $I S O 6060$ 1989, using LCK 114 digestion vials from Hach Lange), and dissolved $\mathrm{P}$ ( $\mathrm{P}_{\text {DISSi }}$ ISO 6878 2004). All analyses were carried out in duplicate.

Concentrations of total particulate nitrogen $\left(\mathrm{TN}_{\mathrm{PART}}\right)$, phosphorus $\left(\mathrm{P}_{\mathrm{PART}}\right), \mathrm{BOD}_{5}\left(\mathrm{BOD}_{5-\mathrm{PART}}\right)$, and $\mathrm{COD}_{\mathrm{PART}}$ were derived as the difference between the corresponding total and dissolved fractions.

In addition to the bi-weekly, $24 \mathrm{~h}$ composite samples, a sampling campaign was carried out during 5 consecutive weeks in October and November 2013 to assess the settling of particles in the wetland. Grab samples $(250 \mathrm{ml})$ were obtained at all 6 sampling stations along the wetland (Stns C, C1, D, D1, E, and F in Fig. 1) once a week using a telescopic pole fitted with a $1.5 \mathrm{l}$ plastic beaker. The beaker was immersed facing upside down and slowly turned to an upright position at the required depth, striving to sample from the centre of the water column. The size distribution of particles (PSD; 5 to $200 \mu \mathrm{m}$ ) in the samples was determined immediately upon return to the laboratory (within $2.5 \mathrm{~h}$ of sampling) using an optical particle counter (AccuSizer ${ }^{\text {TM }} 780$ SIS; Particle Sizing Systems), and particle numbers and volumes were calculated following the procedures described by Fernandes et al. (2014). 


\section{Statistics and modelling}

The relative size distribution of particles measured at the wetland inlet Stn $\mathrm{C}$ and outlet Stn F was compared using a $t$-test checking for normality (ShapiroWilk), equal variance (Brown-Forsythe), and power of the test.

Average yearly net nutrient concentrations measured at Stns C, D, E, and F were calculated based on the bi-weekly composite samples obtained during the sampling year, assuming a constant flow in the wetland determined by the constantly pumped intake of water into the farm. Outliers including negative values of $\mathrm{TN}_{\mathrm{PART}}, \mathrm{P}_{\mathrm{PART}}, \mathrm{BOD}_{5 \text {-PART, }}$ and CODPART, and the few values smaller or larger than the mean \pm 2 SD were excluded from the data set prior to analysis.

The data were subjected to 1-way ANOVA analysis followed by a Holm-Šidák multiple comparison test in case of significant differences. In case the normality test (Shapiro-Wilk) failed, the 1-way ANOVA analysis was run on ranks followed by a Tukey multiple comparison test.

Longitudinal transect data were modelled using a modified first order kinetic plug flow model (Kadlec \& Knight 1996) assuming other components of the water budget (precipitation, evapotranspiration, infiltration etc.) to be negligible compared to the dominant flow: $C-C^{*}=\left(C_{0}-C^{*}\right) \times \mathrm{e}^{(-k A / q)}$, where $C$ is the concentration of the modelled component (i.e. nutrient fraction [mg l$~^{-1}$ ] or particle numbers [no $\left.\mathrm{ml}^{-1}\right]$ and volume $\left[\mathrm{mm}^{3} \mathrm{ml}^{-1}\right]$ ) at different sampling stations along the wetland, $C^{*}$ is the apparent background concentration of the component, $C_{0}$ is the inflow concentration of the component to the wetland, $k_{A}$ is the area-based removal rate constant $\left(\mathrm{m} \mathrm{d}^{-1}\right)$, and $q$ is the horizontal flow velocity $\left(\mathrm{m} \mathrm{d}^{-1}\right)$ equal to the specific hydraulic loading rate at each sampling station. The latter was calculated as the total flow into the wetland $\left(12960 \mathrm{~m}^{3} \mathrm{~d}^{-1}\right)$ divided by the total FWS area $\left(\mathrm{m}^{2}\right)$ preceding each sampling station (cf. Table 1).

The model predicts that the concentration of the modelled component decreases in an exponential manner towards a background (residual) concentration $\left(C^{*}\right)$. Kadlec \& Wallace (2009) have reported background concentrations for most nutrients, but for $\mathrm{TN}, \mathrm{BOD}_{5}, \mathrm{COD}$, and $\mathrm{P}$ only as lumped/total components. The lowest concentration of the dissolved and particulate fractions of these components measured during the monitoring period (including measurements in the stream intake water cf. Stn A in Fig. 1) was therefore used as a background value.
For TAN and $\mathrm{NO}_{2}-\mathrm{N}$, a background concentration of zero was applied following Kadlec \& Wallace (2009). The background concentration for $\mathrm{NO}_{3}-\mathrm{N}$ was set as the lowest concentration measured in the intake water given that the fish farm was located in an intensively cultivated (/fertilized) region where zero concentrations are never reached (Wiberg-Larsen et al. 2013).

The model was fitted to data from each sampling date by minimizing the sum of squared residuals between observed and predicted values using the Solver GRG non-linear function in Microsoft Excel ${ }^{\circledR}$.

The first order removal rate constants of the different nutrient components were plotted against time of sampling to assess potential seasonal fluctuations. Furthermore, Person Product Moment Correlation analysis was carried out between the removal rate constants of $\mathrm{BOD}_{\mathrm{PART}}, \mathrm{BOD}_{5-\mathrm{DISS}}$ and TAN, respectively and the average wetland oxygen concentrations measured at the 2 most downstream sampling stations.

All statistical analyses were carried out using SigmaPlot 13 software (Systat), and differences were considered significant at $\mathrm{p}<0.05$.

\section{RESULTS}

\section{Temperature and oxygen}

The temperature in the wetland decreased from approximately $13.5^{\circ} \mathrm{C}$ in summer to $1.5^{\circ} \mathrm{C}$ in winter (Fig. 2a). Oxygen concentrations were always highest at the inlet station, fluctuating between 8 and 10 $\mathrm{mg} \mathrm{l}^{-1}$ throughout the year (Fig. 2b). The concentration decreased progressively as the water travelled through the wetland and seasonal fluctuations became increasingly pronounced. For example, oxygen concentrations down to $2 \mathrm{mg} \mathrm{O}_{2} \mathrm{l}^{-1}$ were recorded furthest downstream in October 2013 compared to $8 \mathrm{mg} \mathrm{O}_{2} \mathrm{l}^{-1}$ at the same station in April 2014.

\section{Particles}

Total particle numbers (Fig. 3a) and volumes (Fig. 3b) measured in grab samples obtained in the wetland during the 5 wk sampling campaign in October and November 2013 decreased in an exponential manner along the wetland towards the lowest concentration measured (533 particles $\mathrm{ml}^{-1}$ or $8.90 \times 10^{-4}$ $\mathrm{mm}^{3} \mathrm{ml}^{-1}$, respectively). The area-based rate constant of the first order kinetic plug flow model fitted 

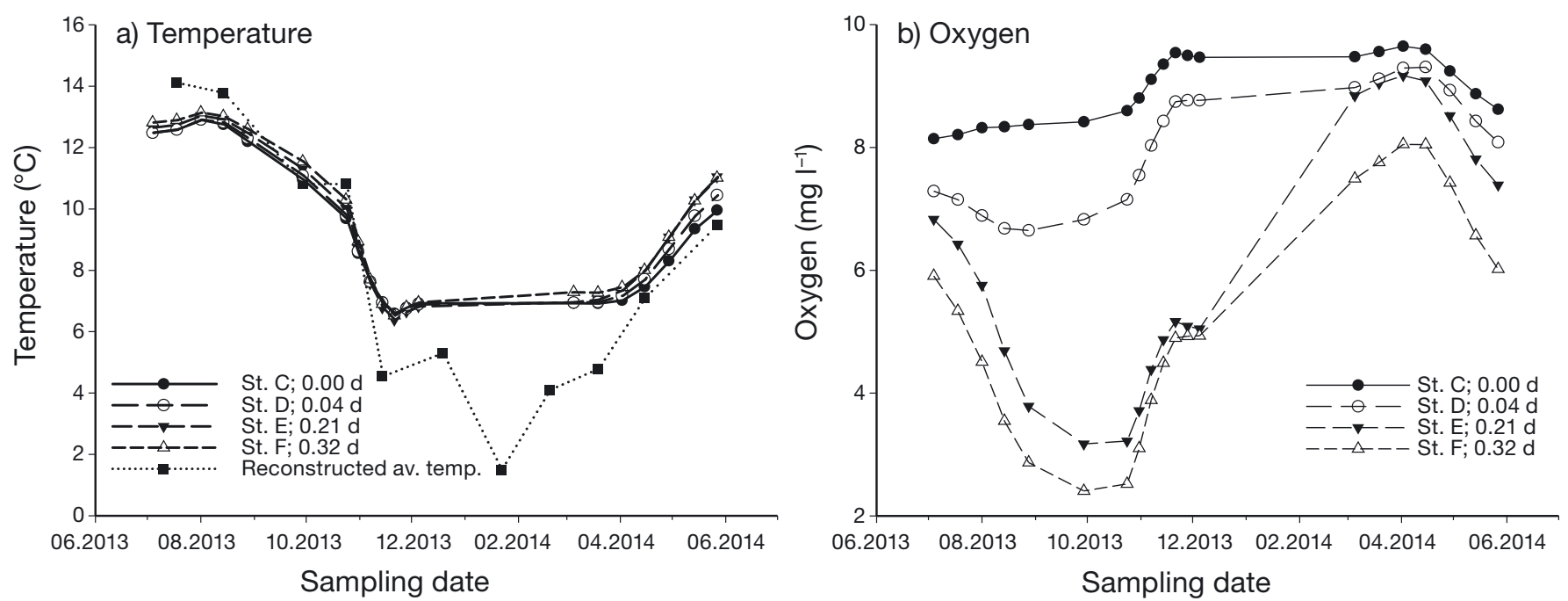

Fig. 2. (a) Temperature and (b) oxygen concentrations measured at increasing hydraulic retention time (HRT, in d) relative to the wetland inlet station (Stn C, cf. Fig. 1) during the year of sampling. Data are shown as running averages of 3 concurrent sampling events. Some temperature and oxygen measurements were missing from the time series and an average temperature was reconstructed based on archival temperature records from DMI (2017). This was done by translating the officially registered average monthly temperatures for the region (Nordjylland, Denmark) to fit the measured, average temperatures in the wetland by multiplying the former by a factor derived by minimizing the sum of squared residuals between the 2 measurements using the Solver GRG non-linear function in Microsoft Excel ${ }^{\circledR}$
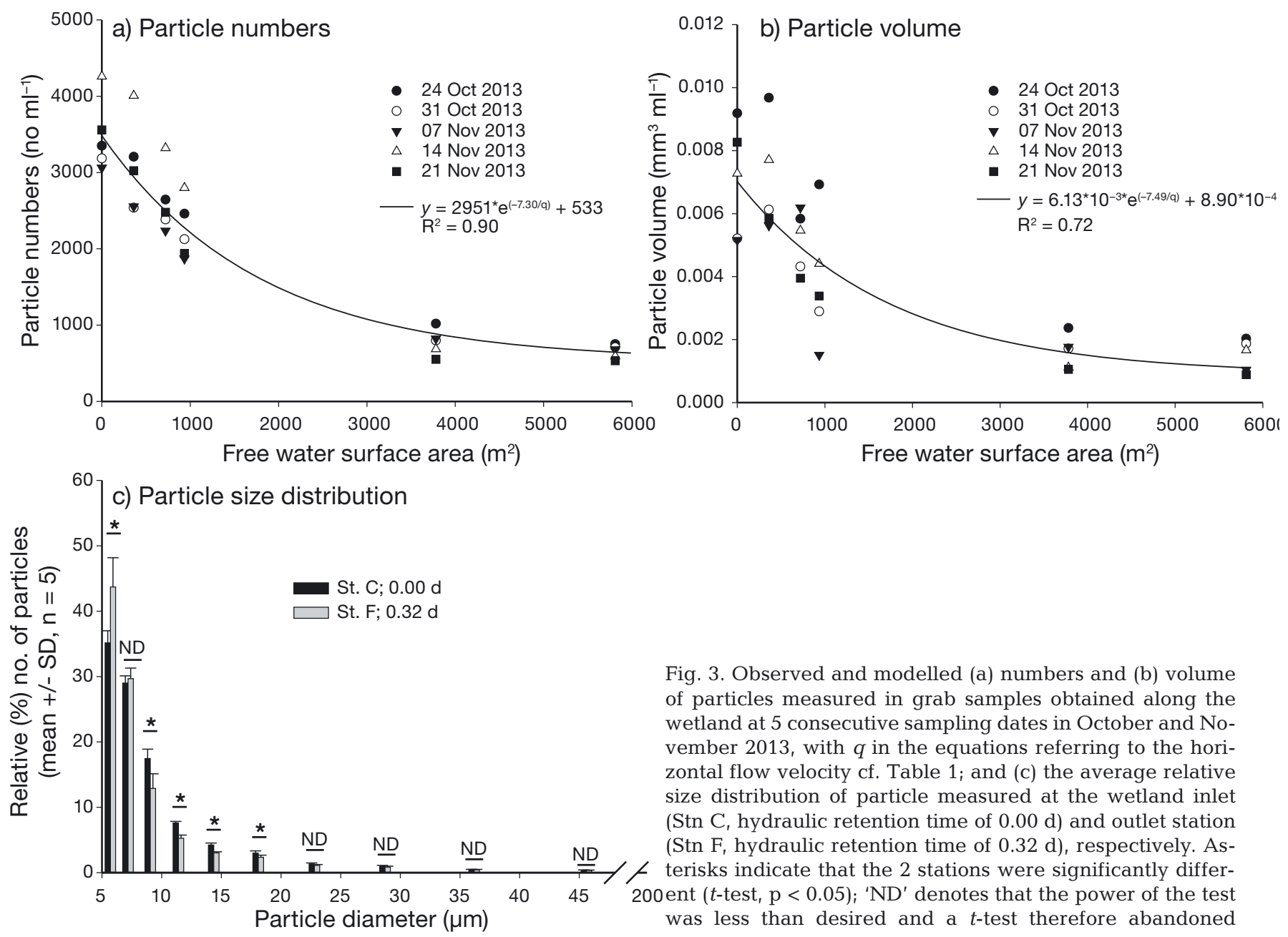

Fig. 3. Observed and modelled (a) numbers and (b) volume of particles measured in grab samples obtained along the wetland at 5 consecutive sampling dates in October and November 2013, with $q$ in the equations referring to the horizontal flow velocity cf. Table 1 ; and (c) the average relative size distribution of particle measured at the wetland inlet (Stn C, hydraulic retention time of $0.00 \mathrm{~d}$ ) and outlet station (Stn F, hydraulic retention time of $0.32 \mathrm{~d}$ ), respectively. Asterisks indicate that the 2 stations were significantly differ200 ent $(t$-test, $\mathrm{p}<0.05)$; 'ND' denotes that the power of the test was less than desired and a $t$-test therefore abandoned 


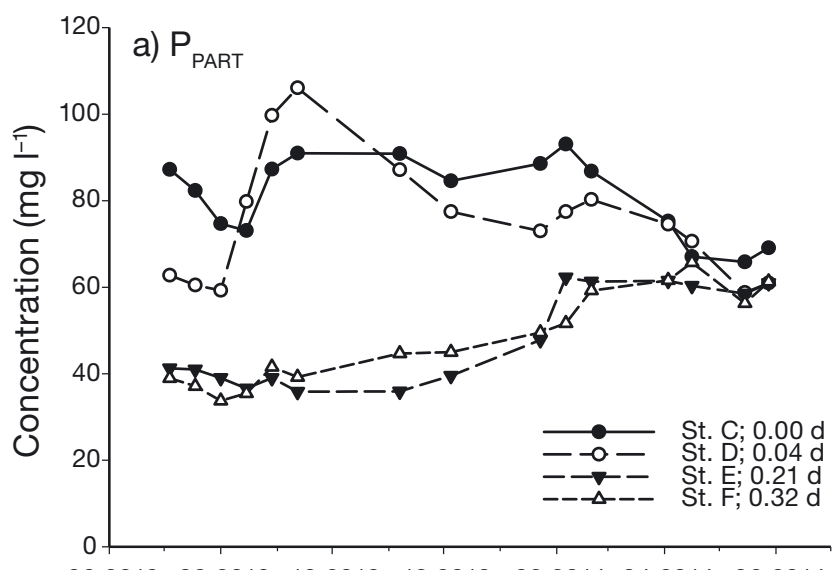

$\begin{array}{lllllll}06.2013 & 08.2013 & 10.2013 & 12.2013 & 02.2014 & 04.2014 & 06.2014\end{array}$

Sampling date
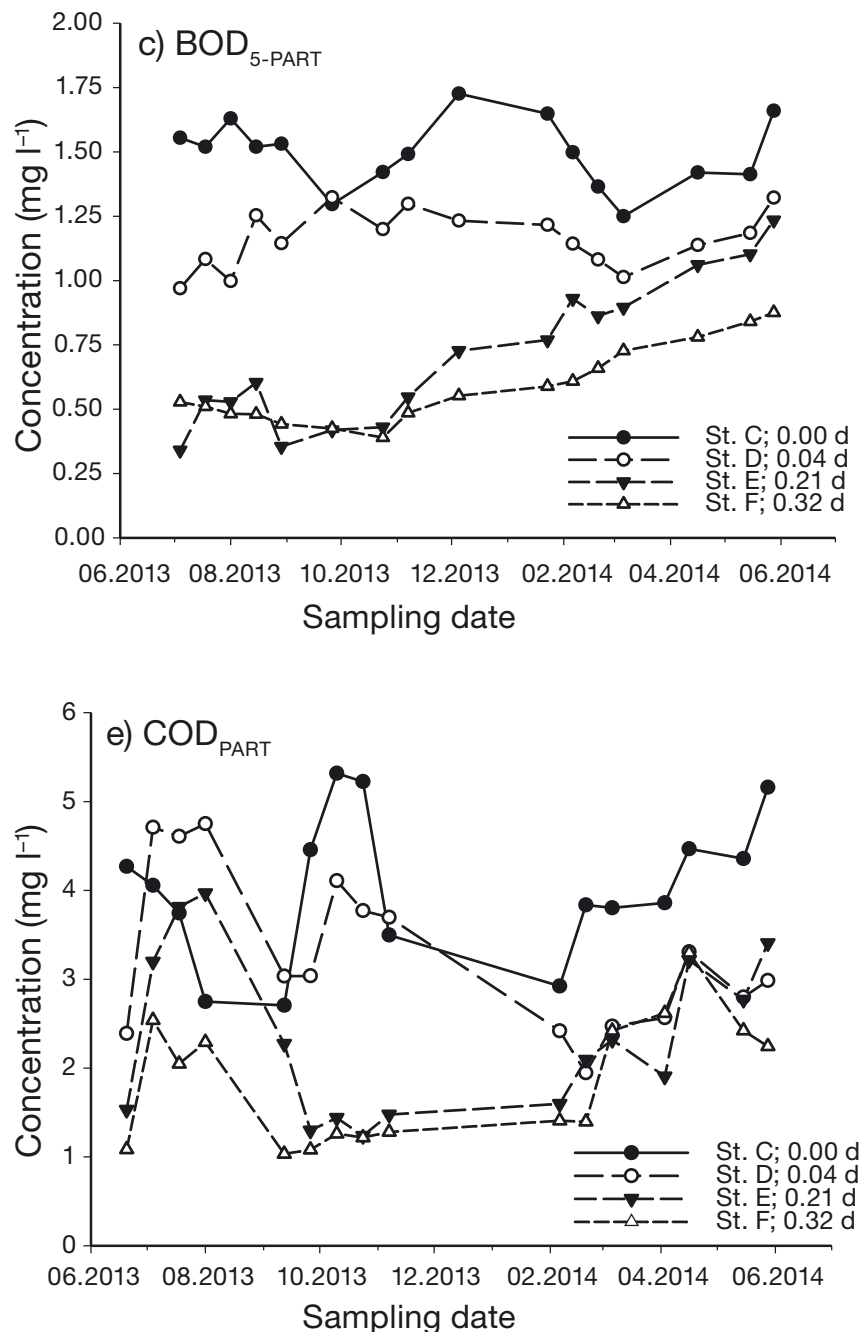
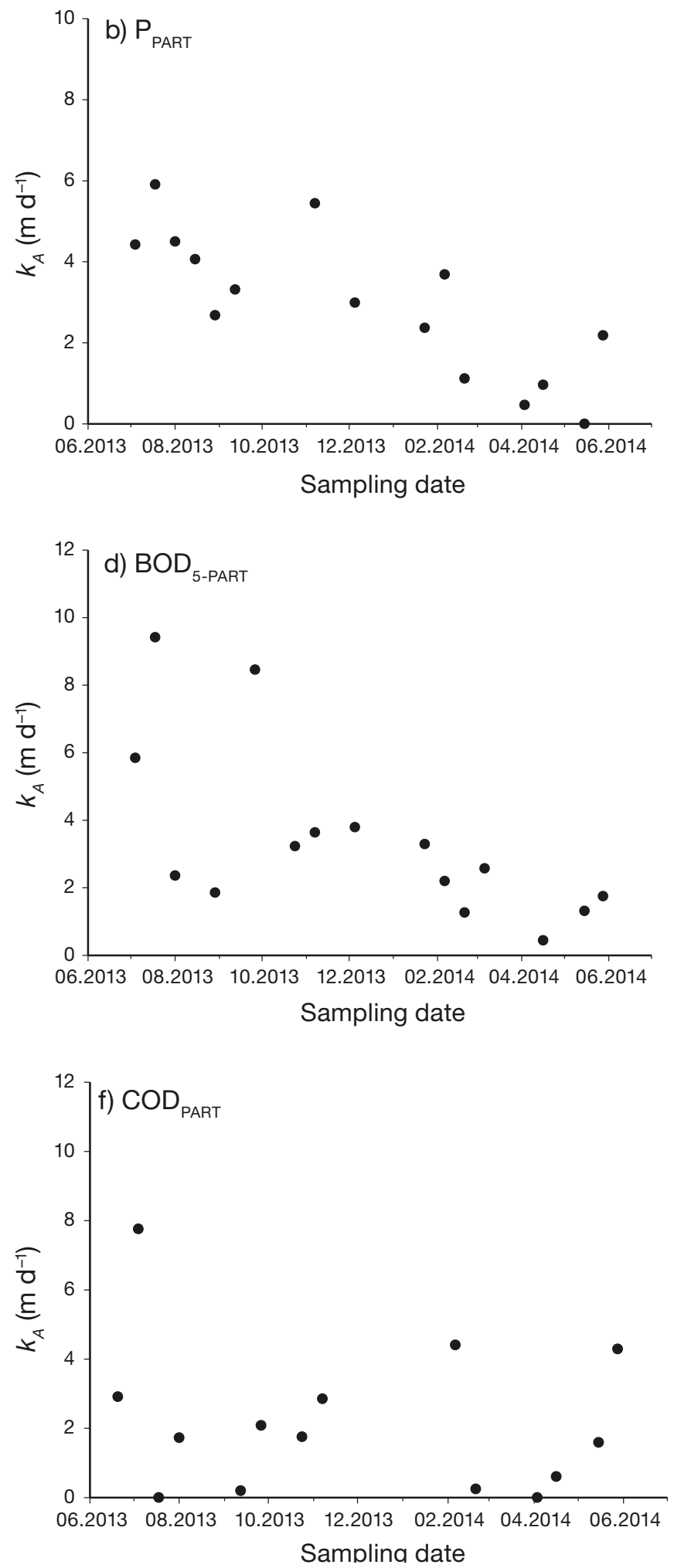

Fig. 4. Concentrations (a,c,e; running averages of 3 concurrent sampling events) of particulate (PART) phosphorus (P; a), $5 \mathrm{~d}$ biochemical $\left(\mathrm{BOD}_{5} ; \mathrm{c}\right)$ and chemical $(\mathrm{COD} ; \mathrm{e})$ oxygen demand measured at increasing hydraulic retention time (HRT, in d) relative to the wetland inlet station (Stn C, cf. Fig. 1) during the year of bi-weekly sampling. Also shown is the corresponding area-based reaction coefficients $\left(k_{A}, \mathrm{~m} \mathrm{~d}^{-1} ; \mathrm{b}, \mathrm{d}, \mathrm{f}\right)$. Background concentrations used for fitting first order kinetic plug flow models to the longitudinal transect data and deriving the $k_{A}$ values are summarized in Table 2 
to the 5 sampling dates averaged $7.3 \pm 1.5$ and $7.5 \pm$ $4.3 \mathrm{~m} \mathrm{~d}^{-1}$ for particle numbers and volume, respectively. Expressing particles by volume rather than numbers increased the variation, and the coefficient of determination $\left(\mathrm{R}^{2}\right)$ of the average model decreased from 0.90 to 0.72 .

The size distribution of the particles changed towards a larger share of smaller particles as the water passed through the wetland, and the relative share of particles in the smallest size class measured (5.0 to $6.4 \mu \mathrm{m}$ in diameter) was significantly larger at the wetland outlet Stn F compared to the wetland inlet Stn C (Fig. 3c).

\section{Particulate nutrient removal}

Fig. 4 shows the concentrations of particulate $\mathrm{P}$ and organic matter measured along the wetland during the sampling year and the accompanying first order removal rate constants. The corresponding yearly average net concentrations are summarized in Table 2, where the background concentrations applied for model fitting are also shown. Particulate $\mathrm{N}$ was excluded from the analyses of particulate nutrients because of very low, and in many cases undetectable, inflow concentrations to the wetland.

The concentrations of $\mathrm{P}_{\mathrm{PART}}$, $\mathrm{BOD}_{5-\mathrm{PART}}$, and CODPART generally decreased with increasing HRT until sampling Stn E, corresponding to a HRT of $0.21 \mathrm{~d}$, while there was little to no further decrease towards the final sampling station at a HRT of $0.32 \mathrm{~d}$ (Fig. 4). Furthermore, the decrease in concentrations with increasing HRT appeared to level off from November to June. The seasonal trends were largely reflected in the yearly average net concentrations, where there were significant differences between the inlet station and Stn E, while there were no differences for any of the measured particulate components between the last 2 sampling stations (Table 2).

The corresponding removal rate constants for $\mathrm{P}_{\mathrm{PART}}$ and $\mathrm{BOD}_{5 \text {-PART }}$ decreased from an initial average in July of approximately 5.1 and $6.5 \mathrm{~m} \mathrm{~d}^{-1}$, respectively to less than $1.0 \mathrm{~m} \mathrm{~d}^{-1}$ for both components in April the following year (Fig. 4). There was no significant correlation between the $\mathrm{BOD}_{5 \text {-PART }}$ removal rate constants and wetland oxygen concentrations.

The removal rate constant for $\mathrm{COD}_{\mathrm{PART}}$ averaged $2.2 \pm 2.2 \mathrm{~m} \mathrm{~d}^{-1}$ and did not decrease in a similar manner as that of $\mathrm{P}_{\mathrm{PART}}$ and $\mathrm{BOD}_{5 \text {-PART }}$ due to more pronounced fluctuations in concentrations in the first part of the wetland in the start of the sampling period.

There appeared to be a minor seasonal cycle in the inlet concentrations of the particulate nutrients, referring especially to $\mathrm{P}_{\mathrm{PART}}$ with slightly higher inlet concentrations in autumn and winter than in spring and summer.

Table 2. Mean ( \pm SD) yearly net concentrations (for $n$ sampling days) of the different dissolved (DISS) and particulate (PART) inorganic nutrients and organic matter components (TN: total nitrogen; TAN: total ammonia nitrogen; $\mathrm{NO}_{2}-\mathrm{N}_{\text {: nitrite-nitrogen; }}$ $\mathrm{NO}_{3}-\mathrm{N}$ : nitrate-nitrogen; $\mathrm{P}$ : phosphorus; $\mathrm{BOD}_{5}: 5 \mathrm{~d}$ biochemical oxygen demand; COD: chemical oxygen demand) measured at increasing hydraulic retention time (HRT; in d) along the wetland, as well as the background concentrations $\left(C^{*}\right)$ used for fitting first order kinetic plug flow models to the longitudinal transect data at individual sampling days. Values in rows followed by different superscript letters were significantly different $(p<0.05)$

\begin{tabular}{|c|c|c|c|c|c|c|}
\hline $\begin{array}{l}\text { Nutrient } \\
\text { component }\end{array}$ & $\begin{array}{c}\text { Stn C } \\
(\text { HRT } 0.00 \mathrm{~d})\end{array}$ & $\begin{array}{c}\text { Stn D } \\
\text { (HRT } 0.04 \text { d) }\end{array}$ & $\begin{array}{c}\text { Stn E } \\
\text { (HRT } 0.21 \mathrm{~d})\end{array}$ & $\begin{array}{c}\text { Stn F } \\
\text { (HRT } 0.32 \mathrm{~d})\end{array}$ & $\mathrm{n}$ & $\begin{array}{c}\text { Background } \\
\text { concentration }\left(C^{*}\right)\end{array}$ \\
\hline $\mathrm{TN}_{\text {PART }}\left(\mathrm{mg} \mathrm{l}^{-1}\right)$ & $0.1 \pm 0.2$ & $0.1 \pm 0.2$ & $0.1 \pm 0.04$ & $0.1 \pm 0.1$ & 14 & $-{ }^{\mp}$ \\
\hline $\mathrm{TN}_{\text {DISS }}\left(\mathrm{mg} \mathrm{l}^{-1}\right)$ & $4.3 \pm 0.25$ & $4.3 \pm 0.23$ & $4.2 \pm 0.27$ & $4.1 \pm 0.29$ & 21 & $1.9^{\mp \mp}$ \\
\hline TAN $\left(\mu g l^{-1}\right)$ & $470 \pm 90^{\mathrm{ab}}$ & $510 \pm 110^{\mathrm{a}}$ & $340 \pm 170^{\mathrm{b}}$ & $290 \pm 180^{b}$ & 21 & $0.0^{\ddagger}$ \\
\hline $\mathrm{NO}_{2}-\mathrm{N}\left(\mu g \mathrm{l}^{-1}\right)$ & $77 \pm 13$ & $80 \pm 23$ & $76 \pm 23$ & $71 \pm 23$ & 25 & $0.0^{\ddagger}$ \\
\hline $\mathrm{NO}_{3}-\mathrm{N}\left(\mathrm{mg} \mathrm{l}^{-1}\right)$ & $3.4 \pm 0.21$ & $3.4 \pm 0.20$ & $3.5 \pm 0.35$ & $3.5 \pm 0.35$ & 25 & $2.1^{\mathrm{II}}$ \\
\hline $\mathrm{P}_{\text {PART }}\left(\mu_{\mathrm{g} \mathrm{l}} \mathrm{l}^{-1}\right)$ & $81 \pm 14^{\mathrm{a}}$ & $75 \pm 21^{\mathrm{a}}$ & $48 \pm 14^{\mathrm{b}}$ & $48 \pm 15^{\mathrm{b}}$ & 15 & $26^{ \pm \pm}$ \\
\hline $\mathrm{P}_{\text {DISS }}\left(\mu g \mathrm{l}^{-1}\right)$ & $44 \pm 18^{\mathrm{a}}$ & $45 \pm 15^{\mathrm{a}}$ & $39 \pm 18^{\mathrm{ab}}$ & $31 \pm 13^{b}$ & 25 & $6^{\text {tx }}$ \\
\hline $\mathrm{BOD}_{5 \text {-PART }}\left(\mathrm{mg} \mathrm{l}^{-1}\right)$ & $1.5 \pm 0.3^{\mathrm{a}}$ & $1.2 \pm 0.2^{\mathrm{b}}$ & $0.7 \pm 0.3^{c}$ & $0.6 \pm 0.2^{\mathrm{c}}$ & 16 & $0.1^{\text {II }}$ \\
\hline $\mathrm{BOD}_{5 \text {-DISS }}\left(\mathrm{mg} \mathrm{l}^{-1}\right)$ & $2.0 \pm 0.5$ & $1.9 \pm 0.4$ & $1.8 \pm 0.7$ & $1.7 \pm 0.5$ & 23 & $0.5^{\text {辛 }}$ \\
\hline $\mathrm{COD}_{\text {PART }}\left(\mathrm{mg} \mathrm{l}^{-1}\right)$ & $4.0 \pm 1.9^{\mathrm{a}}$ & $3.3 \pm 2.0^{\mathrm{ab}}$ & $2.3 \pm 1.8^{\mathrm{b}}$ & $1.8 \pm 1.4^{\mathrm{b}}$ & 16 & $0.2^{\text {社 }}$ \\
\hline $\mathrm{COD}_{\text {DISS }}\left(\mathrm{mg} \mathrm{l}^{-1}\right)$ & $7.0 \pm 1.9$ & $7.1 \pm 1.6$ & $7.0 \pm 1.7$ & $7.2 \pm 1.6$ & 16 & $2.9^{\mathrm{t1}}$ \\
\hline \multicolumn{7}{|c|}{ 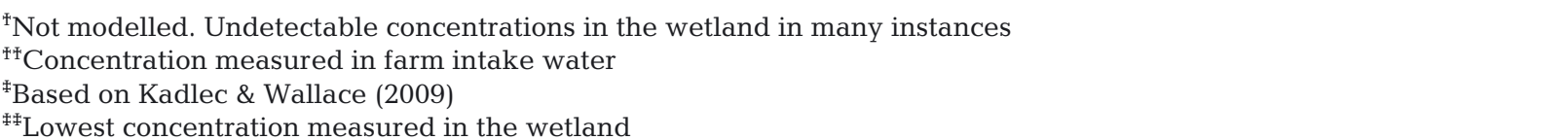 } \\
\hline
\end{tabular}




\section{Dissolved nutrient removal dynamics}

Dissolved P and organic matter

The inflow concentrations of $P_{\text {DISS }}$ to the wetland were very low (Table 2) and, similarly to $\mathrm{P}_{\mathrm{PART}}$, appeared to fluctuate in a seasonal manner with slightly higher inflow concentrations in late autumn to early spring compared to the other half of the sampling period (Fig. 5). The fluctuations were largely mirrored as the water travelled through the wetland and there was a general, small decrease in concentrations with increasing HRT. Consistent with this, there was a significant decrease in the yearly average net concentration between sampling Stns D and F corresponding to an increase in HRT from 0.04 to $0.32 \mathrm{~d}$. There was no seasonal trend in the removal rate constant for $\mathrm{P}_{\text {DISS }}$ averaging $0.7 \pm 0.4 \mathrm{~m} \mathrm{~d}^{-1}$ throughout the sampling period.

Inlet concentrations of $\mathrm{BOD}_{5 \text {-DISS }}$ seemed to vary in a slightly opposite manner to that of $\mathrm{P}_{\text {DISS }}$ (Fig. 5). The concentration appeared to decrease along the wetland between July and January until a HRT of $0.21 \mathrm{~d}$, while there seemed to be a small net production of $\mathrm{BOD}_{5 \text {-DISS }}$ from March to June. Consistent with this, there were no significant differences in the yearly average net concentrations from Stns C to F (Table 2). The corresponding removal rate constant for $\mathrm{BOD}_{5 \text {-DISs }}$ was principally zero from February to July, while it averaged $1.2 \mathrm{~m} \mathrm{~d}^{-1}$ from July to the middle of January. The $\mathrm{BOD}_{5 \text {-DISS }}$ removal rate constant correlated negatively with the average dissolved oxygen concentrations at the 2 most downstream sampling stations $(\mathrm{r}=-0.796, \mathrm{n}=15, \mathrm{p}<0.001)$.

The inlet concentrations of $\mathrm{COD}_{\text {DISS }}$ were approximately 3.5-fold higher than those of $\mathrm{BOD}_{5 \text {-DISS }}$ but unlike the latter, there was only a miniscule decrease in concentration along the wetland restricted to the period from October to February, where $k_{A}$ averaged $0.3 \pm 0.1 \mathrm{~m} \mathrm{~d}^{-1}$ (Fig. 5). Similar to BOD 5 -DISS, there was a small net production of $\mathrm{COD}_{\text {DISS }}$ in the wetland from March to June and there were no significant differences in the yearly average net concentrations along the wetland (Table 2).

\section{Dissolved N}

Fig. 6 and Table 2 summarize the concentrations of the dissolved $\mathrm{N}$ compounds measured along the wetland and the corresponding first order removal rate constants. The inlet concentration of $\mathrm{TN}_{\mathrm{DISS}}$ fluctuated in a seasonal manner, increasing slightly from
June to October and decreasing from February to April. The trend was largely mirrored throughout the wetland and there was little or no decrease in concentrations as the HRT increased. There was consequently no significant difference in the yearly average net $\mathrm{TN}_{\text {DISS }}$ concentrations (Table 2), and the removal rate constant was very low, averaging $0.2 \pm$ $0.1 \mathrm{~m} \mathrm{~d}^{-1}$ throughout the sampling year.

The $\mathrm{TN}_{\text {DISS }}$ concentration pattern concealed some large fluctuations in the other measured dissolved $\mathrm{N}$ compounds, most noticeably TAN, which constituted approximately $11 \%$ of the incoming $\mathrm{TN}_{\text {DISS. There }}$ was generally a small net production of TAN in the very first part of the wetland throughout the year, while there was a net removal from April to October as the HRT increased from 0.04 to $0.32 \mathrm{~d}$, reflected partly in the yearly average net concentrations. The corresponding removal rate constant fluctuated in a distinct seasonal manner, peaking at $3.9 \mathrm{~m} \mathrm{~d}^{-1}$ in October and decreasing to zero in February and March. There was a strong, negative correlation between TAN removal rate constants and the average dissolved oxygen concentrations at the 2 most downstream sampling stations $(\mathrm{r}=-0.831, \mathrm{n}=15, \mathrm{p}<0.001)$.

$\mathrm{NO}_{2}-\mathrm{N}$ constituted less than $2 \%$ of the inflowing $\mathrm{TN}_{\text {DISS }}$ and the concentrations in the wetland fluctuated more or less similarly to that of TAN, although less distinct. The corresponding net removal rate constant was lower than that of TAN, peaking at $1.4 \mathrm{~m} \mathrm{~d}^{-1}$ in November. In comparison, there was a small net production of $\mathrm{NO}_{2}-\mathrm{N}$ in the wetland from May to September (Fig. 6).

$\mathrm{NO}_{3}-\mathrm{N}$ constituted by far the largest fraction of $\mathrm{TN}_{\text {DISS }}(80 \%$; Table 2$)$ in the wetland, but unlike TAN and $\mathrm{NO}_{2}-\mathrm{N}$, there was very little removal as the water travelled through the wetland (Fig. 6). On the contrary, there was a small net production of $\mathrm{NO}_{3}-\mathrm{N}$ from July to January within the area delimited by sampling Stn E situated after a HRT of $0.21 \mathrm{~d}$ while there was a miniscule net removal from February to July, where $k_{A}$ averaged $0.1 \pm 0.1 \mathrm{~m} \mathrm{~d}^{-1}$. There were no significant differences comparing the yearly average net concentrations at the different sampling stations (Table 2).

\section{DISCUSSION}

\section{Particle sedimentation}

Sedimentation of solids is one of the main removal processes in a FWS wetland (Kadlec \& Wallace 2009). Particles settle if their sinking velocity $\left(V_{\mathrm{s} i} \mathrm{~m} \mathrm{~h}^{-1}\right)$ ex- 

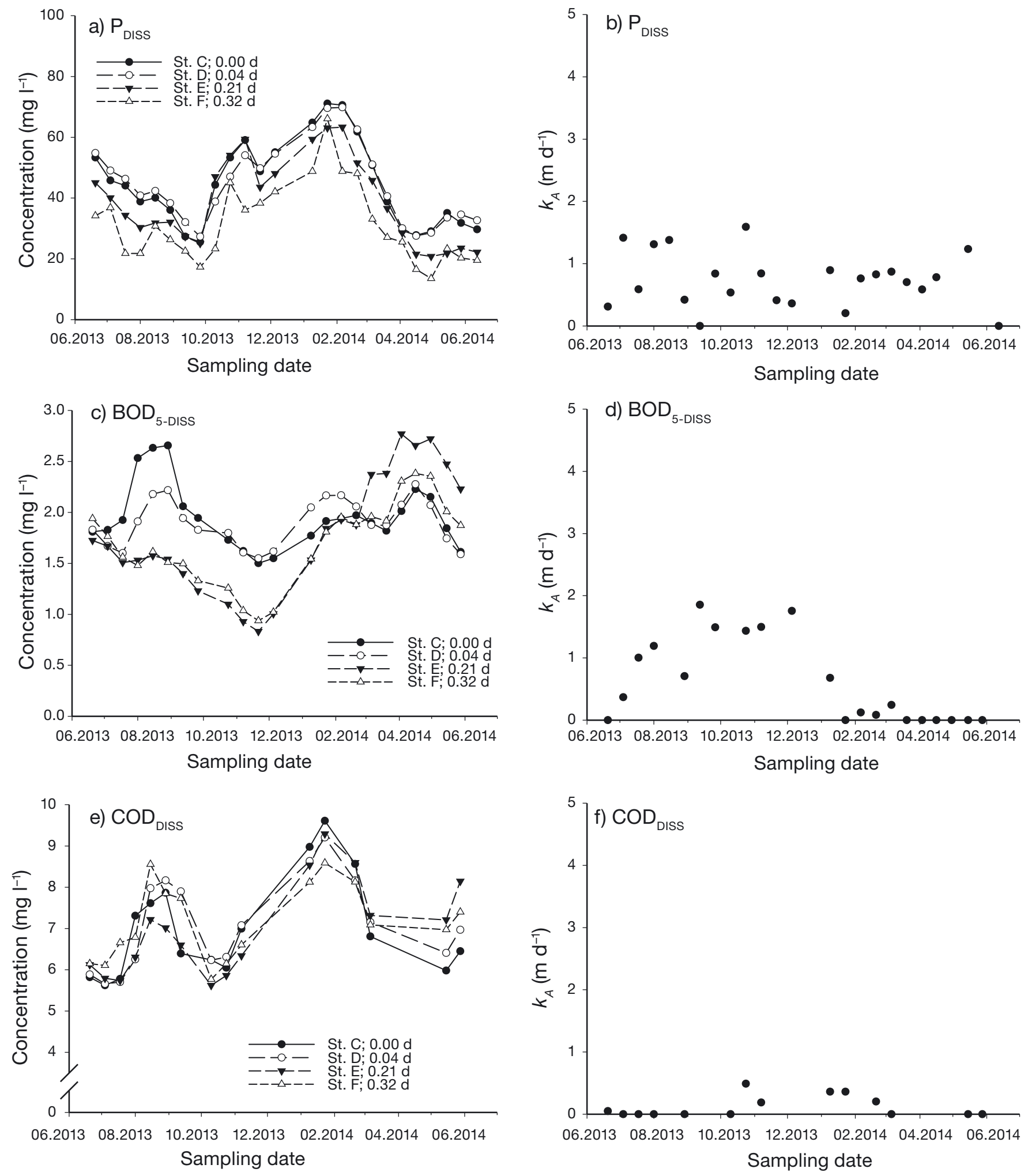

Fig. 5. Concentrations (a,c,e; running averages of 3 concurrent sampling events) of dissolved (DISS) phosphorus (P; a), $5 \mathrm{~d}$ biochemical $\left(\mathrm{BOD}_{5} ; \mathrm{c}\right)$ and chemical (COD; e) oxygen demand measured at increasing hydraulic retention time (HRT, in d) relative to the wetland inlet station (Stn C, cf. Fig. 1) during the year of bi-weekly sampling. Also shown is the corresponding area-based reaction coefficients $\left(k_{A}, \mathrm{~m} \mathrm{~d}^{-1} ; \mathrm{b}, \mathrm{d}, \mathrm{f}\right)$. Background concentrations used for fitting first order kinetic plug flow models to the longitudinal transect data and deriving the $k_{A}$ values are summarized in Table 2 

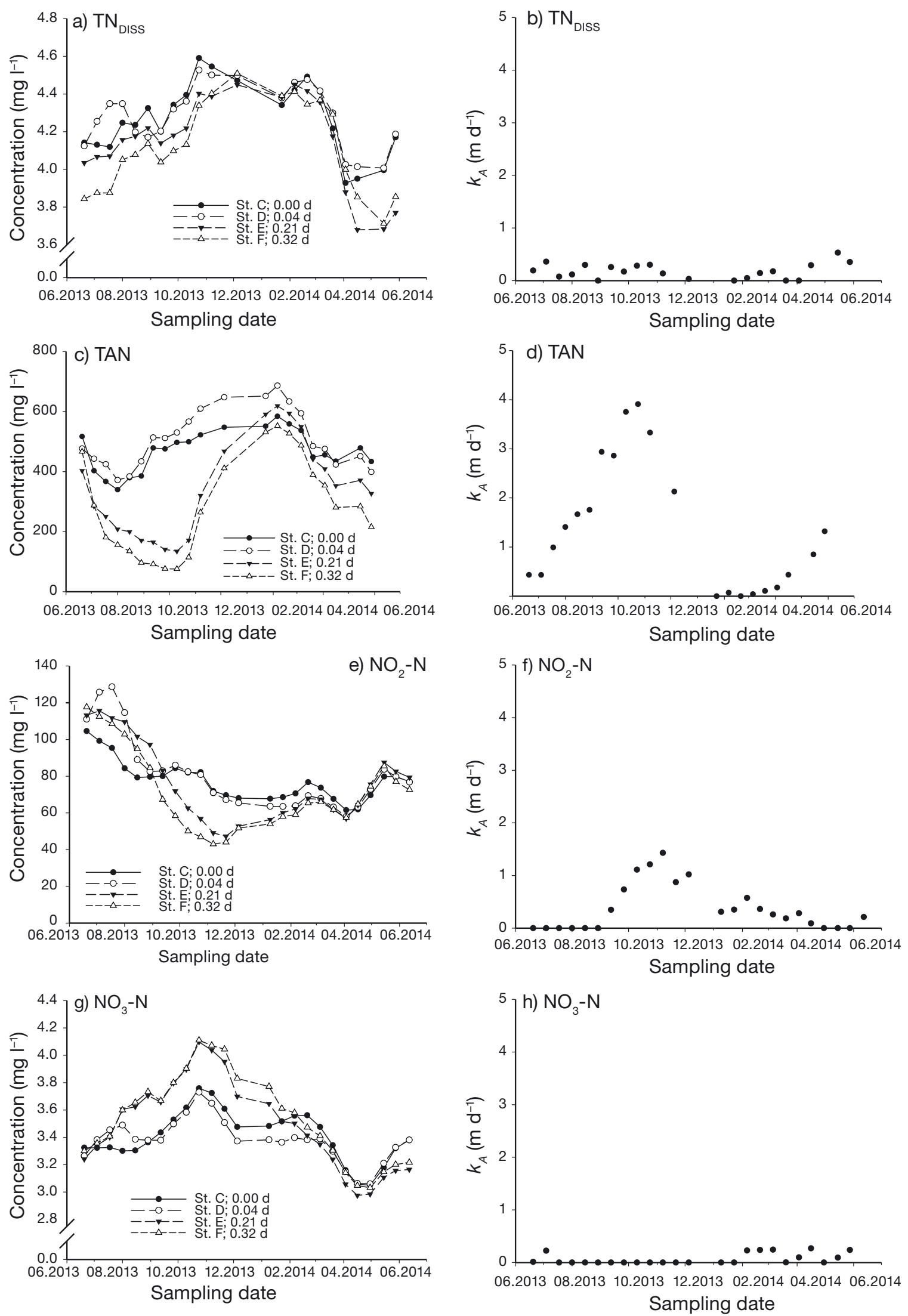

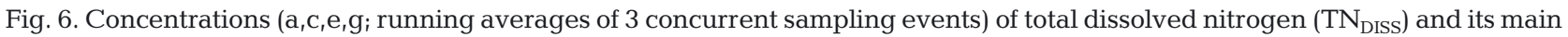
constituents (TAN, $\mathrm{NO}_{2}-\mathrm{N}, \mathrm{NO}_{3}-\mathrm{N}$ ) measured at increasing hydraulic retention time (HRT; in d) relative to the wetland inlet station (Stn C, cf. Fig. 1) during the year of bi-weekly sampling. Also shown are the corresponding area-based reaction coefficients $\left(k_{A} ;\right.$ in $\left.\mathrm{md}^{-1} ; \mathrm{b}, \mathrm{d}, \mathrm{f}, \mathrm{h}\right)$. Background concentrations used for fitting first order kinetic plug flow models to the longitudinal transect data and deriving the $k_{A}$ values are summarized in Table 2 
ceeds the horizontal flow velocity $\left(Q / A_{;} \mathrm{m} \mathrm{h}^{-1}\right)$ (Chen et al. 1993, Lekang 2013), i.e. particles should theoretically settle in the current wetland if the time needed for sedimentation is shorter than the HRT in the wetland. The density of particles in a wetland is seldom known (Kadlec \& Wallace 2009); however, particles of aquaculture origin consist primarily of organic matter with a more or less similar density (Chen et al. 1993, Patterson et al. 2003). Given a similar density, and following Stokes' law, this means that particles deriving from the adjacent aquaculture system should principally settle along the wetland according to size. Consistent with this, the exponential decrease in particle numbers and volume towards an apparent background level as the HRT increased indicates that larger particles settled within the first part of the wetland, leaving a 'weathered' fraction of smaller, non-settable particles (Fig. 3a,b). This is further supported by the size distribution data, showing that the relative share of particles smaller than $8 \mu \mathrm{m}$ in diameter increased as the water travelled through the wetland (Fig. 3c).

The particle settling profile sustains the validity of fitting a first order model to the particulate matter data within the observed loading range. Many wetland processes are basically first order, and removal of lumped contaminants such as $\mathrm{TBOD}_{5}, \mathrm{TCOD}$, and TSS has previously been modelled as such with or without taking hydraulic conditions into consideration (Kadlec \& Wallace 2009). Water in the current wetland was assumed to move as a plug flow given the river-like design, and the high correlation coefficients of the first order kinetic plug flow model fitted to the particle number and volume data supported this assumption.

The decrease in the correlation coefficient when expressing particles as volume instead of numbers indicates that the size of particles entering the wetland was affected by daily operation routines at the farm, and/or that the density of the different particles entering the wetland was not constant. Given the size of the wetland, the final discharge of particles was, however, not affected by such variations, as the background level for both particle numbers and volume was approached long before the final wetland outlet.

\section{Particulate nutrient removal}

Longitudinal removal of particulate nutrients

Nutrients sorb to suspended solids (Kadlec 2003), which, in the current wetland primarily consisted of organic matter from the fish farm combined with any particles from the intake stream water that had not been removed within the production unit. The settling of particles in the wetland discussed in the above section therefore implies a concurrent removal of adsorbed and contained nutrients and organic matter. It also implies that the removal of particulate nutrients in the wetland followed an equivalent first order process.

Particulate $\mathrm{BOD}_{5}, \mathrm{COD}$, and $\mathrm{P}$ concentrations decreased asymptotically along the wetland, resulting in very similar concentrations at the 2 most downstream sampling stations (Fig. 4). A similar asymptotic decrease in $\mathrm{TBOD}_{5}, \mathrm{TCOD}$, and TP towards nonzero background levels has been observed in previous wetland studies, where it reportedly comprised hard-to-degrade substances and wetland return fluxes (reviewed by Kadlec \& Wallace 2009). The findings are also consistent with Schulz et al. (2004), who found good removal efficiencies of TSS, TCOD, and TP in small $\left(350 \mathrm{~m}^{2}\right)$ wetlands treating effluents from a flow-through fingerling farm, reportedly due to settling of solids.

Following the settling profiles, the removal of particulate nutrients essentially took place within the first $65 \%$ of the wetland FWS area corresponding to a HRT of $0.21 \mathrm{~d}$. Hence, this first part of the wetland principally acted as a settling basin for particulate $\mathrm{P}$ and organic matter.

The wetland was seldom cleaned, and the apparently limited removal of particulate nutrients in the most upstream part of the wetland, i.e. the area between a HRT of 0 and $0.04 \mathrm{~d}$ (Table 2, Fig. 4), was probably due to random perturbations and intermittent resuspension of build-up solids. In comparison, Schulz et al. (2004) found no effect of TSS loading rate on solid resuspension in FWS wetlands of sizes comparable to the inlet zone in the current study, and discussed that this was due to management of the wetlands which were cleaned and dried out from November to May.

Seasonal removal of particulate nutrients

Despite that settling is a physical process that is only weakly affected by temperature (Kadlec \& Reddy 2001), there were clear seasonal patterns in the removal rate constants of $\mathrm{P}_{\mathrm{PART}}$ and to some extent $\mathrm{BOD}_{5 \text {-PART }}$ (Fig. 4). Given the infinitesimal variations in inlet concentrations during the year, the rate constants in the current study largely reflect the actual mass removal of the measured components (i.e. $\mathrm{g} \mathrm{m}^{-2} \mathrm{~d}^{-1}$ ). It may therefore be deduced from the 
rate constant profiles that there was a high removal of $\mathrm{P}_{\text {PART }}$ and $\mathrm{BOD}_{5-\mathrm{PART}}$ during summer and autumn, whereas there was almost no removal in spring. The removal patterns seem to mirror the growth cycle of the naturally developing wetland vegetation (authors' pers. obs.). Submerged and emerged plants thus developed visually along the wetland during summer (Fig. 7) when removal rates were highest, and the vegetation presumably assisted in removing nutrients by trapping and retaining particles as observed in other wetland studies (e.g. Gerke et al. 2001, Svendsen et al. 2008). The reduction in plant cover towards the end of the growing season may similarly explain the gradual decline in particulate nutrient removal rates towards spring. The vegetation was not removed from the wetland, and $\mathrm{P}$ as well as organic matter that was trapped by and stored in the litter may have been partly released back into the system following microbial decomposition of the decaying litter. Hence, the gradual lack of plant cover combined with a continuous breakdown of detritus may explain that the removal of particulate $\mathrm{P}$ and organic matter continued at an insignificant rate in spring when the growth of plants was at a minimum.

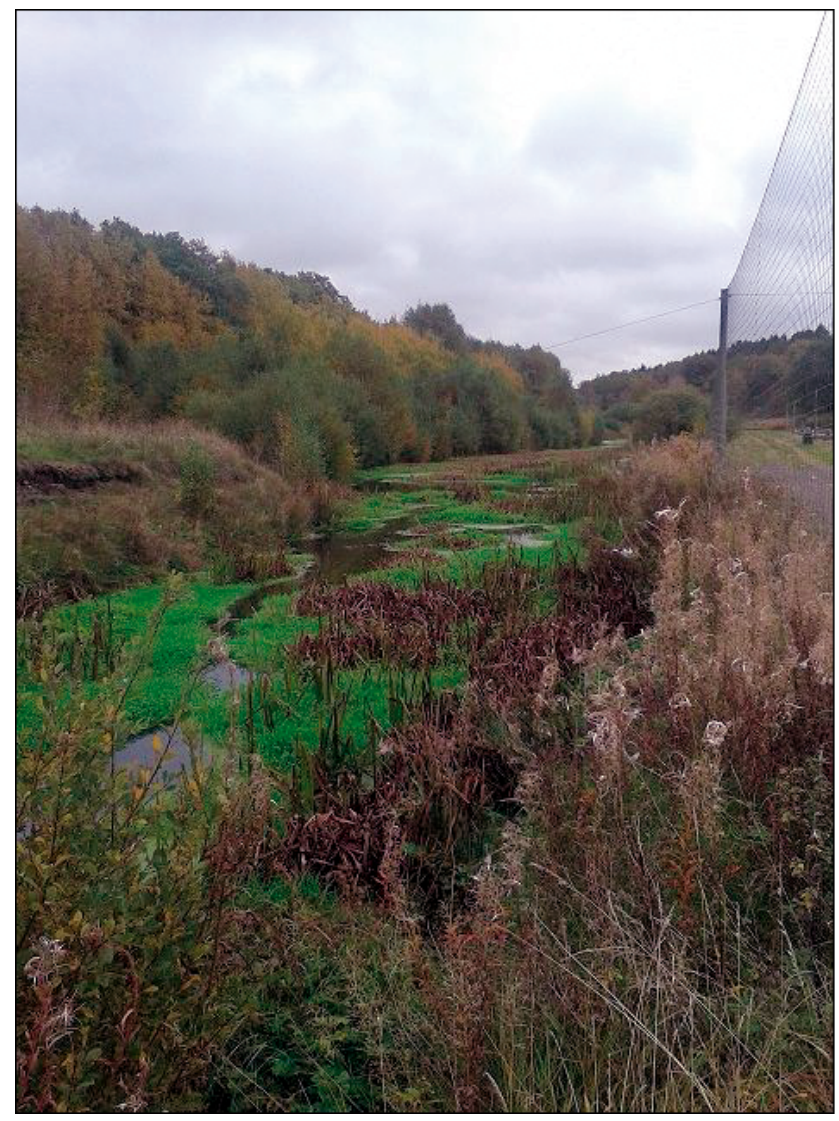

The lack of a similar seasonal trend in the removal rate constant of $\mathrm{COD}_{\mathrm{PART}}$ probably reflected that COD is a measure of both easy- and hard-todegrade organic matter. Measurements of COD are consequently more easily affected by random wetland events such as phytoplankton blooms, particle re-suspension, bioturbation, or gas release from the sediment than measurement of BOD $_{5 \text {-PART. The }}$ magnitude of such events might be amplified by a low density, flocculent layer developing above the sediment. Treatment wetlands applied for low-level nutrient removal (such as in the current study) have thus been shown to develop a flocculent layer above the sediment consisting of detrital material with a very low density (reviewed by Kadlec \& Wallace 2009). The material is normally not transported but it is very mobile if disturbed. The existence and disturbance of such a layer of recalcitrant compounds and bacteria would, similarly to phytoplankton growth, explain that the concentrations of $\mathrm{COD}_{\text {PART }}$ and $\mathrm{P}_{\text {PART }}$ at one point increased above the inflow concentration, while there was no similar increase in easy-to-degrade BOD $_{5-P A R T}$ (Fig. 4).

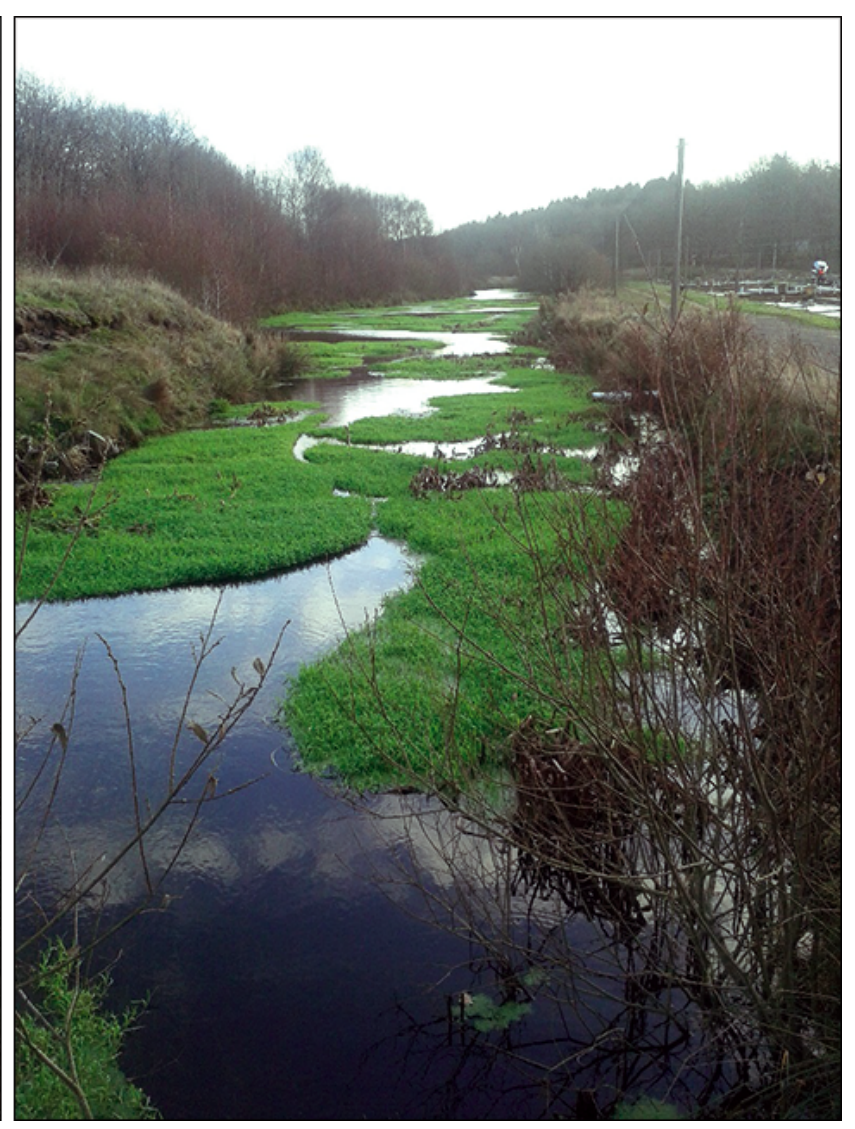

Fig. 7. The wetland in October (left) and at the end of November (right) towards the end of the growing season 


\section{Summary of particulate nutrient removal}

The exponential decrease in particles and particulate nutrient concentrations with increasing HRT combined with a seasonal growth cycle and a potential development of a flocculent bottom layer shows that the wetland, beyond the point where the background concentrations were approached (i.e. $0.21 \mathrm{~d}$ ), had no additional effect on particulate nutrient removal. Rather, a longer retention time in this type of wetland might increase the risk of particle resuspension (Kadlec \& Wallace 2009).

\section{Dissolved nutrient removal}

TAN and dissolved $\mathrm{BOD}_{5}$ removal

Whereas the removal of particulate nutrients was most likely due to sedimentation, the removal of dissolved nutrients was more likely coupled to various microbially mediated wetland processes. This may be deduced from the longitudinal decrease in oxygen concentrations from April to November (Fig. 2) and the negative correlations between $\mathrm{BOD}_{5 \text {-DISS }}$ and TAN removal rates, respectively and the average dissolved oxygen concentration at the 2 most downstream sampling stations. The longitudinal decrease in oxygen presumably reflected the activity of heterotrophic and autotrophic bacteria breaking down dissolved organic matter and converting TAN to $\mathrm{NO}_{3}-\mathrm{N}$, respectively (Zhu \& Chen 2002, Svendsen et al. 2008, Kinyage \& Pedersen 2016). Both processes consume oxygen and are temperature-dependent, which may explain that there was essentially neither nitrification (Fig. 6c,d) nor removal of BOD 5 -Diss (Fig. 5c,d) taking place in the coldest months, as also observed in many other treatment wetlands (reviewed by Kadlec \& Wallace 2009).

The increase in TAN net removal from April to October as the HRT increased from 0.04 to $0.32 \mathrm{~d}$ is consistent with Schulz et al. (2004), who also found that more ammonia was removed as the HRT increased (from 3.5 to $11 \mathrm{~h}$ ) in small $\left(350 \mathrm{~m}^{2}\right)$, aquaculture-related FWS wetlands operated from May to October under comparable environmental conditions.

In addition to microbially mediated removal, TAN may be taken up directly by wetland plants during the growing season (Gerke et al. 2001). However, the major role of the wetland plants in the current study was probably to provide surface area for nitrifying bacteria (Svendsen et al. 2008, reviewed by Kadlec \& Wallace 2009). This would explain that TAN (and $\mathrm{NO}_{2}-\mathrm{N}$ ) re- moval rates peaked by the end of the growing season in November when the plant biomass, and consequently available surface area, was highest (based on visual assessment and similarly to what has been observed in MTF III wetlands cf. Svendsen et al. 2008).

\section{Nitrate removal}

Nitrate removal in treatment wetlands is typically driven by heterotrophic denitrification. Wetland plants may also take up nitrate but they usually do so to a much smaller extent than they take up ammonia because nitrate must be reduced before the plants can make use of it (reviewed by Kadlec \& Wallace 2009). Neither denitrification nor plant uptake, however, appears to have taken place to any large extent in the studied wetland. Rather, there was a net production of $\mathrm{NO}_{3}-\mathrm{N}$ from July to January (Fig. 6), i.e. more nitrate leaving the wetland than entering. The removal of TAN in autumn was thus largely counterbalanced by a net production of nitrate, explaining that there was no net removal of $\mathrm{TN}_{\text {DISS }}$ in the wetland during the year (Table 2, Fig. 6). In comparison, an average of $2.7 \mathrm{~g} \mathrm{NO}_{3}-\mathrm{N} \mathrm{m}^{-2} \mathrm{~d}^{-1}$ was removed in the 8 MTF III wetlands monitored by Svendsen et al. (2008) that were characterized by a higher nutrient loading (averaging $10.0 \mathrm{mg} \mathrm{l}^{-1} \mathrm{TBOD}_{5}$ and $6.6 \mathrm{mg} \mathrm{l}^{-1}$ $\mathrm{NO}_{3}-\mathrm{N}$ ) and longer HRT (20 to $50 \mathrm{~h}$ ).

Denitrification in the current wetland was most likely limited by the availability of organic carbon combined with the high oxygen concentrations. An optimal BOD/ $\mathrm{NO}_{3}-\mathrm{N}$ ratio of 2.3 has been reported for complete microbial denitrification to take place under controlled anaerobic conditions, with BOD reerring to dissolved organic matter (Narkis et al. 1979). A higher $\mathrm{BOD}_{5} / \mathrm{NO}_{3}-\mathrm{N}$ ratio of 5 to 9 has been suggested for a similar process to take place in the field (reviewed by Kadlec \& Wallace 2009, Hang et al. 2016). In comparison, the incoming $\mathrm{BOD}_{5 \text {-DISS }} /$ $\mathrm{NO}_{3}-\mathrm{N}$ ratio in the current study averaged $0.58 \pm 0.16$ $\left(1.07 \pm 0.17\right.$ for $\left.\mathrm{BOD}_{\mathrm{TOT}} / \mathrm{NO}_{3}-\mathrm{N}\right)$, which is far below the ratio necessary for driving full denitrification of the incoming nitrate load. Denitrification might still have proceeded in certain areas where there was an accumulation of settled organic matter, such as at the sediment surface in the first part of the wetland. The high oxygen concentration in this part of the wetland was, however, not conducive for denitrification, and most of the organic carbon might have been degraded by aerobic respiration.

In addition to incoming carbon, the decomposition of plants may also supply carbon for denitrification 
(reviewed by Kadlec \& Wallace 2009, Hang et al. 2016). However, the biomass of the naturally developing vegetation seems to have been too low to fuel an extensive denitrification activity also given the oxygen continuously provided by the water flow.

\section{Dissolved P removal}

The constant, low removal of $\mathrm{P}_{\text {DISS }}$ (Fig. 5a,b) was probably due to a combination of sediment sorption, biomass build-up, and/or storage of newly created, refractory residuals in the sediment (Kadlec \& Wallace 2009). A previous study with radioactively labelled phosphorus $\left({ }^{32} \mathrm{P}\right)$ showed that dissolved $\mathrm{P}$ may be taken up within minutes by microorganisms in the water column and converted to particles $(>0.45 \mu \mathrm{m})$. The particulate P may subsequently be cycled into periphyton and flocs via particle settling, filtration, and mineralisation (Noe et al. 2003). A similar rapid uptake of dissolved $\mathrm{P}$ by microorganisms may have taken place in the current study, explaining the low consistent removal of $\mathrm{P}_{\text {DISS }}$ throughout the wetland.

Temperature seems to have little effect on $\mathrm{P}$ sequestration in general in wetlands (reviewed by Kadlec \& Wallace 2009), and consistent with this, there was no seasonal cycle in the $\mathrm{P}_{\text {DISS }}$ removal rate constant. Rather, the fluctuations in $\mathrm{P}_{\text {DISS }}$ concentrations in the wetland were due to fluctuations in the inlet concentrations reflecting operational conditions at the fish farm. Hence, a reduction in fish size, reduced feeding levels, and/or a change in the type of feed applied may all explain the observed decrease in dissolved and particulate P inflow concentrations observed in the start and end of the sampling period (Dalsgaard \& Pedersen 2011).

\section{Summary of dissolved nutrient removal}

The strength of wastewater entering the wetland was very low compared to e.g. municipal effluent or wastewater deriving from industries or livestock production. The inlet concentrations of $\mathrm{BOD}_{5 \text {-DISs }}$ and BOD $_{5-P A R T}$ were, for example, below the apparent background concentration for total BOD reported by Kadlec \& Wallace (2009) for various FWS treatment wetlands. Microorganisms in the wetland were therefore essentially substrate-limited, sustained by the fact that the longitudinal nutrient reductions in concentrations were well described by a first order kinetic model.

Given the low inlet concentrations, the overall mass removal of dissolved nutrients was low, and for TAN,
$\mathrm{NO}_{2}-\mathrm{N}$, and $\mathrm{BOD}_{5-\mathrm{DISS}}$ further dictated by the seasonally fluctuating removal rate constants including periods of no removal. This, combined with the fact that there was no net removal but rather a net production at certain times of $\mathrm{NO}_{3}-\mathrm{N}$, shows that the wetland in its current design and with the short HRT was largely inefficient at removing dissolved nutrients.

\section{CONCLUSIONS}

The longitudinal changes in nutrient concentrations were adequately modelled by a first order kinetic plug flow model, and the study provides a first set of removal rate estimates that may contribute to predicting outlet concentrations and masses from similar types of aquaculture treatment wetlands with short HRTs and similar loading and climate conditions.

The treatment performance of MTF type I wetlands has so far been a 'black box' constructed with the belief that area-based MTF type III removal rates apply here as well, and that 'bigger therefore is better'. The current study, however, showed that nutrients in a FWS wetland treating aquaculture effluent at a short HRT were primarily removed by, or due to, sedimentation of particles, and there was no yearly net removal of dissolved nutrients aside from an infinitesimal removal of $\mathrm{P}_{\text {DISS }}$. Rather, there was a net production of $\mathrm{NO}_{3}-\mathrm{N}$ during certain periods of the year, demonstrating that the area-based $\mathrm{TN}$ removal rates from MTF type III treatment wetlands do not apply to MTF type I treatment wetlands.

The study highlights that MTF type I treatment wetlands in their current layout and operated with short HRTs do not favor the removal of dissolved nutrients, and that they may be largely over-dimensioned in terms of removing particulate nutrients. Future efforts should therefore focus on ways to improve the treatment efficiency of MTF type I treatment wetlands. This could, for example, include adding organic carbon and creating anaerobic zones in the most upstream section to promote microbial denitrification, or installing denitrifying woodchip bioreactors (von Ahnen et al. 2016) after the initial sedimentation zone.

Acknowledgements. This research was funded by the Ministry of Food, Agriculture and Fisheries of Denmark and by the European Union through the European Fisheries Fund (EFF). The authors thank Ulla Sproegel, Brian Møller, and Dorthe Frandsen (DTU Aqua) for invaluable technical assistance in the laboratories as well as Ole Madvig Larsen, Rasmus Frydenlund Jensen, and Remko Oosterveld (DTU Aqua) for their technical assistance in the field. 


\section{LITERATURE CITED}

Carvalho PN, Arias CA, Brix H (2017) Constructed wetlands for water treatment: new developments. Water 9:397

Chen S, Timmons MB, Aneshansley DJ, Bisogni JJ Jr (1993) Suspended solids characteristics from recirculating aquacultural systems and design implications. Aquaculture 112:143-155

* Dalsgaard J, Pedersen PB (2011) Solid and suspended/dissolved waste $(\mathrm{N}, \mathrm{P}, \mathrm{O})$ from rainbow trout (Oncorynchus mykiss). Aquaculture 313:92-99

Danish Ministry of Environment (2006) Bekendtgørelse om modeldambrug. Bekendtgørelse nr. 1327 af 20. november 2006, Lovtidende A, Miljøministeriet, Copenhagen

Danish Ministry of Environment (2012) Bekendtgørelse om miljøgodkendelse og samtidig sagsbehandling af ferskvandsdambrug. Lovtidende A nr. 130. Miljøstyrelsen, Miljøministeriet, Copenhagen

DMI (Danish Meteorological Institute) (2017) The Danish Meteorological Institute. www.dmi.dk (accessed 9 Jun 2017)

DS 223 (1991) Water analysis - determination of the sum of nitrite- and nitrate-nitrogen. Danish Standards Foundation, Charlottenlund

DS 224 (1975) Water analysis - determination of ammonianitrogen. Danish Standards Foundation, Charlottenlund

Fernandes PM, Pedersen LF, Pedersen PB (2014) Daily micro particle distribution of an experimental recirculating aquaculture system - a case study. Aquacult Eng 60: $28-34$

Gerke S, Baker LA, Xu Y (2001) Nitrogen transformations in a wetland receiving lagoon effluent: sequential model and implications for water reuse. Water Res 35: 3857-3866

Hang Q, Wang H, Chu Z, Ye B, Li C, Hou Z (2016) Application of plant carbon source for denitrification by constructed wetland and bioreactor: review of recent development. Environ Sci Pollut Res Int 23:8260-8274

ISO 11905-1 (1997) Water quality - determination of nitrogen. Part 1: Method using oxidative digestion with peroxodisulfate. International Organization for Standardization, Geneva

ISO 5815-2 (2003) Water quality - determination of biochemical oxygen demand after $\mathrm{n}$ days (BODn). Part 2: Method for undiluted samples, ISO 5815-2:2003, modified. International Organization for Standardization, Geneva

ISO 6060 (1989) Water quality - determination of the chemical oxygen demand. International Organization for Standardization, Geneva

ISO 6878 (2004) Water quality - determination of phosphorus-ammonium molybdate spectrometric method. International Organization for Standardization, Geneva

ISO 7890-1 (1986) Water quality - determination of nitrate. Part 1: 2.6-dimethylphenol spectrometric method. International Organization for Standardization, Geneva

Jokumsen A, Svendsen LM (2010) Farming of freshwater rainbow trout in Denmark. DTU Aqua Rep 219-2010, Technical University of Denmark, Copenhagen

Kadlec RH (2003) Effects of pollutant speciation in treatment wetlands design. Ecol Eng 20:1-16

Kadlec RH, Knight RL (1996) Treatment wetlands. CRC Press, Boca Raton, FL

Editorial responsibility: Catriona MacLeod,

Hobart, Tasmania, Australia
Kadlec RH, Reddy KR (2001) Temperature effects in treatment wetlands. Water Environ Res 73:543-557

Kadlec RH, Wallace SD (2009) Treatment wetlands, 2nd edn. CRC Press, Boca Raton, FL

Kinyage JPH, Pedersen LF (2016) Impact of temperature on ammonium and nitrite removal rates in RAS moving bed biofilters. Aquacult Eng 75:51-55

Lekang OI (2013) Aquaculture engineering, 2nd ed. WileyBlackwell, Chichester

*Lin YF, Jing SR, Lee DY, Chang YF, Chen YM, Shih KC (2005) Performance of a constructed wetland treating intensive shrimp aquaculture wastewater under high hydraulic loading rate. Environ Pollut 134:411-421

Mitch WJ, Gosselink J (2015) Wetlands, 5th edn. John Wiley \& Sons, Hoboken, NJ

Narkis N, Rebhun M, Sheindorf CH (1979) Denitrification at various carbon to nitrogen ratios. Water Res 13:93-98

Noe GB, Scinto LJ, Taylor J, Childers DL, Jones RD (2003) Phosphorus cycling and partitioning in an oligotrophic Everglades wetland ecosystem: a radioisotope tracing study. Freshw Biol 48:1993-2008

Patterson RN, Watts KC, Gill TA (2003) Micro-particles in recirculating aquaculture systems: determination of particle density by density gradient centrifugation. Aquacult Eng 27:105-115

Pedersen PB, Grønborg O, Svendsen LM (eds) (2003) Modeldambrug. Specifikationer og godkendelseskrav. Rapport fra faglig arbejdsgruppe. Arbejdsrapport fra DMU nr. 183, Danmarks Miljøundersøgelser, Miljøministeriet, Copenhagen

Schulz C, Gelbrecht J, Rennert B (2003) Treatment of rainbow trout farm effluents in constructed wetland with emergent plants and subsurface horizontal water flow. Aquaculture 217:207-221

Schulz C, Gelbrecht J, Rennert B (2004) Constructed wetlands with free water surface for treatment of aquaculture effluents. J Appl Ichthyol 20:64-70

Sindilariu PD, Schulz C, Reiter R (2007) Treatment of flowthrough aquaculture effluents in a constructed wetland. Aquaculture 270:92-104

Sindilariu PD, Wolter C, Reiter R (2008) Constructed wetland as a treatment method for effluents from intensive trout farms. Aquaculture 277:179-184

Sindilariu PD, Brinker A, Reiter R (2009) Factors influencing the efficiency of constructed wetlands used for the treatment of intensive trout farm effluent. Ecol Eng 35: 711-722

Svendsen LM, Sortkjær O, Ovesen NB, Skriver J and others (2008) Modeldambrug under forsøgsordningen. Faglig slutrapport for måle- og dokumentationsprojekt for modeldambrug. DTU Aqua Res Rep 193-08, Technical University of Denmark, Copenhagen

*von Ahnen M, Pedersen PB, Dalsgaard J (2016) Start-up performance of a woodchip bioreactor operated end-ofpipe at a commercial fish farm - a case study. Aquacult Eng 74:96-104

Wiberg-Larsen P, Windolf J, Bøgestrand J, BaattrupPedersen A and others (2013) Vandløb 2012, NOVANA. Aarhus Universitet, DCE — Nationalt Center for Miljø og Energi, Denmark. Videnskabelig rapport fra DCE Nationalt Center for Miljø og Energi nr. 75

Zhu S, Chen S (2002) The impact of temperature on nitrification rate in fixed film biofilters. Aquacult Eng 26:221-237

Submitted: January 4, 2018; Accepted: May 14, 2018

Proofs received from author(s): July 17, 2018 